\title{
INOVASI PESANTREN DALAM MEMBENTUK KEMANDIRIAN LEMBAGA DAN SANTRI
}

\author{
Siti Nurjanah \\ Institut Agama Islam Negeri Metro \\ Email: siti.nurjanah@metrouniv.ac.id \\ M. Kholis Amrullah \\ Institut Agama Islam Negeri Metro \\ Email: kholisamrullah@metrouniv.ac.id
}

\begin{abstract}
Pesantren as a place to gain religious knowledge that is simple and does not charge a lot of money. In facing the times, pesantren are required to be independent, and santri are also required to be independent when they enter the community. This study aims to reveal the innovations of pesantren in establishing independence through the results of several studies related to pesantren activities in developing and improving the quality of pesantren and their students. The results of this study indicate that pesantren provide students with religious knowledge, entrepreneurship skills, and social skills to prepare students to enter real life.
\end{abstract}

Keywords: Pesantren, independence, innovations.

\section{A. Pendahuluan}

Pilihan orang tua untuk mendaftarkan anaknya sebagai seorang santri juga adalah pilihan tepat. Karena pesantren mengembangkan potensi ekonomi santri, yang mana ini akan menciptakan kemandirian pesantren itu sendiri. ${ }^{1}$ Hal ini kembali kepada niat dari santri sendiri dan wali santri atau orang tua santri ketika memasukkan anaknya ke pesantren. Sekarang ini, melalui inovasi pesantren dalam bidang pendidikan dan kewirausahaan, maka pesantren menjadi salah satu rujukan lembaga pendidikan bagi masyarakat. Apalagi seiring berjalannya waktu, semakin lama pesantren semakin menjamur. Semakin banyak pesantren, maka semakin banyak juga santri dan alumni santri yang sudah terjun ke masyarakat. Maka menjadikan pesantren sebagai salah satu pilihan utama adalah keputusan yang tepat. Digitalisasi menjadi hal yang paling dibutuhkan dalam kehidupan. Semua lini kehidupan penuh dengan hal-hal digital. Tidak terkecuali kehidupan di pesantren yang kebanyakan dikenal oleh masyarakat umum sebagai tempat dimana hal-hal yang berbau digital ditiadakan. Identitas pesantren bagi masyarakat tempat belajar bagi masyarakat yang menginginkan ilmu agama secara mendalam. Kehidupan di pesantren sangat sederhana,

1 Ugin lugina, Pengembangan Ekonomi Pondok Pesantren di Jawa Barat, Risalah, Vol. 4, No. 1, 2018, h. 53-64. 
seluruh waktu didedikasikan untuk mempelajari ilmu pengetahuan agama. Pesantren tidak lagi menjadi hal yang baru bagi kebanyakan masyarakat di nusantara. Kesederhanaan inilah yang menjadikan fasilitasfasilitas yang ada di pesantren diadakan secukupnya saja.

Pesantren sebagai sebuah lembaga yang berdiri sendiri tanpa ada pihak berwenang kecuali pengasuh sendiri yang berhak untuk mengambil keputusan. Pernyataan ini menunjukkan bahwa pesantren memiliki kemandirian dari segi pengelolaan pendidikan yang ada di dalamnya. Tidak terkecuali tentang kemandirian dalam berpikir dan berkembang sesuai dengan kapasitas yang dimiliki oleh pesantren tersebut. Ekonomi adalah salah satu dari sisi kehidupan yang akan terus bergelut dengan manusia sepanjang usianya. Begitu juga dengan pesantren, pergerakan ekonomi di pesantren sangatlah dinamis. Ditelisik dari kacamata masyarakat yang menganggap bahwa pesantren itu adalah lembaga pendidikan paling sederhana, maka hal ini menjadikan adanya gap antara pengeluaran dan pemasukan dari pesantren. Tenaga pendidikan di pesantren tidak mengenal dengan adanya gaji bulanan seperti pada sekolah formal yang di bawah naungan pemerintah. Kebanyakan tenaga pendidikan tidak memiliki pendapatan tetap dari kegiatan mengajarnya di pesantren. Di samping itu, pesantren juga dikenal dengan biaya pendidikan termurah, dengan besarnya pengeluaran operasional dan kebutuhan masyarakat pesantren harus ditutupi oleh manajemen pesantren itu sendiri.

Penelitian ini bertujuan untuk mengungkapkan hasil-hasil penelitian yang telah dilakukan oleh para peneliti pesantren di Indonesia. Hasil penelitian yang dipilih adalah hasil penelitian yang masih baru, artinya tidak lebih dari lima tahun. Sehingga data dan informasi dari hasil penelitian tersebut masih terasa hangat. Penelitian ini menggunakan pendekatan kualitatif yang berusaha untuk memunculkan makna melalui penginterpretasian dari data. Data pada penelitian ini adalah temuantemuan penelitian dari artikel jurnal yang berkaitan dengan perkembangan dan peningkatan pesantren. Teknik analisis yang digunakan pada penelitian ini yaitu teknik deskriptif kualitatif. Teknik deskriptif kualitatif digunakan peneliti untuk menyederhanakan datadata yang berisi informasi menjadi kesimpulanyang mudah dipahami.

\section{B. Pembahasan}

Pesantren menjadi percontohan dalam membangun ekonomi masyarakat yang mengutamakan pada kepemilikan sesuai syariah, pemanfaatan kepemilikan, dan distribusi kepemilikan masyarakat yang berdasarkan mekanisme syariah. ${ }^{2}$ Pesantren tidak hanya menjadi sebuah lembaga pendidikan, tetapi juga merupakan sebuah penggerak ekonomi

2 Ahmad Fauzi, Pengembangan Ekonomi Islam di Pesantren Jawa Timur, Al-Ulum, Vol. 17, No. 1, 2017, h. 100-119. 
yang berbasis syariah. Hasil dari penelitian Fauzi pada beberapa pesantren di Jawa Timur mengindikasikan bahwa pesantren sudah siap untuk bersaing dengan dunia global. Selain melibatkan santri, pesantren juga melibatkan masyarakat sekitar untuk membantu perputaran roda ekonomi. Roda ekonomi tidak hanya bisa berjalan jika tidak berdasarkan bantuan atau dukungan dari masyarakat yang mana merupakan bagian dari pengembang ekonomi pesantren selain masyarakat pesantren itu sendiri.

Inovasi salah satu pesantren seperti Pesantren Darussalam di Ciamis menggunakan model Bank Wakaf Mikro (BWM) untuk mendongkrak ekonomi masyarakat melalui kegiatan pendidikan yang berisi pengetahuan tentang tauhid; keimanan; ibadah; muamalah; bisnis islam; dan pendampingan yang berperan sebagai pengontrol pinjaman. 3 Kelebihan dari pesantren ini adalah mengunggulkan adanya pendidikan mengenai kewirausahaan atau interpreneurship bagi pesantren dan masyarakat sekitar pesantren. Pendidikan disini tidak hanya dalam konsep belajar mengejar mengenai kegiatan muamalah saja, tetapi juga menerapkan adanya praktik setelah pemberian materi. Sehingga memudahkan bagi santri dan masyarakat untuk memperoleh pengetahuan mengenai tata usaha yang berbasis syariah. Salah satu produknya yang diunggulkan adalah Bank Wakaf Mikro. Melalui lembaga keuangan ini, para penggunanya yaitu santri dan masyarakat dapat mengambil keuntungan berupa adanya program simpan pinjam yang dilakukan pendampingan. Pendampingan dibutuhkan untuk mengontrol penggunaan dan pengelolaan dari pinjaman tersebut, sehingga praktik muamalah yang terjadi pada kegiatan perekonomian ini sejalan dengan maqashid syariah.

Berdirinya sebuah pesantren tidak hanya tempat belajar masyarakat, tetapi sebagai pengontrol persoalan yang muncul di masyarakat. ${ }^{4}$ Sebuah pesantren tidak hanya menjadi tempat mencari ilmu melainkan juga sebagai pemecah dan pengontrol dari masalah sosial. Perubahanperubahan selalu dilakukan oleh pesantren, jika dulu pesantren hanya mengatasi permasalahan hukum islam, maka sekarang pesantren sudah terjun ke dalam dunia digital. Tidak luput juga pesantren mengadakan pengajian online ketika masa pandemic covid-19. Ada yang menggunakan live streaming melalui aplikasi seperti Facebook, Youtube, dan Instagram. Perubahan yang paling relevan dengan digitalisasi adalah inovasi pada bidang ekonomi dan digitalisasi ekonomi pesantren. Pesantren dewasa ini sudah banyak mengembangkan potensi ekonominya seperti pemanfaatn

${ }^{3}$ Siti Nurhayati, Nurjamil, Model Pemberdayaan Ekonomi Masyarakat Miskin melalui Akses pembiayaan Bank Wakaf Mikro Berbasis Pesantren (Studi Kasus LKM Syariah Ranah Indah Darussalam Ciamis), Eco-Iqtishodi, Vol. 1, No. 1, 2019, h. 45-56.

${ }^{4}$ Toha Maksum, Muh. Barid Nizarudin Wajdi, Pengembangan Kemandirian Pesantren Melalui Program Santripreneur, Jurnal Pengabdian Kepada Masyarakat, Vol. 2, No. 2, 2018, h. 221-232. 
hasil kebun dan pertanian, serta pendirian lembaga keuangan yang tentunya berbasis syariah. Sedangkan inovasi pada digitalisasi ekonomi, pesantren sudah ada yang menggunakan software khusus yang digunakan sebagai media untuk pembayaran pembiayaan santri selama di pesantren.

Pentingnya kemandirian ekonomi pada kehidupan pesantren memerlukan implikasi secara bertahap terhadap santri sebagai individu di dalam pesantren. Pendidikan Kemandirian Ekonomi memerlukan adanya keberagaman usaha yang ada di pondok pesantren untuk mengenalkan santri pada kehidupan ekonomi yang nyata. ${ }^{5}$ Misjaya dan rekan-rekan mengusulkan perlunya sebuha pesantren memiliki badan usaha sendiri untuk kemajuan pesantren tersebut. Maka dalam rangka memajukan ekonomi yang mandiri pada pesantren, diperlukan adanya kepedulian pesantren utnuk menghadirkan pelaku-pelaku ekonomi yang handal sebagai tutor maupun model yang akan mengajrkan dan membimbing santri atau masyarakat pesantren. Pada dasarnya, santri telah memiliki bekal keilmuan tentang perdagangan dan sudah mengetahui hukum perkara yang ada dalam ranah ekonomi. Akan tetapi, ketika berhadapan dengan praktik yang terjadi di masyarakat, yang pastinya sangat dinamis, maka disinilah letak kelemahan santri ketika hanya mempelajari tanpa bersentuhan langsung dengan kegiatan ekonomi yang berlaku di masyarakat. Sebenarnya pengembangan pesantren dalam ranah ekonomi ini juga sekaligus memberikan lahan bagi santri untuk mengamalkan ilmu-ilmu yang didapatnya selama belajar di pesantren.

Strategi kopontren yang dikelola oleh santri memerlukan adanya manajemen pada kelembagaan, keanggotaan, kepengurusan, keuangan, kemitraan, dan pengembangan unit usaha agribisnis dalam peningkatan kesejahteraan pesantren dan masyarakat. ${ }^{6}$ Kopontren merupakan bagian dari pondok pesantren yang berfokus pada pengelolaan keuangan pesantren. Konsep sederhana yang diusung oleh kopontren adalah membeli barang kebutuhan harian santri seperti kitab, alat tulis, makanan ringan, dan kebutuhan santri lainnya yang yang memiliki harga yang terjangkau dan tidak bersifat sekunder maupun tersier. Semua pesantren di Indonesia memiliki koperasi, hanya saja pengelolaannya yang variatif. Pengelolaan kopontren yang variatif ini didasarkan pada jumlah santri dan kompetensi pengelola koperasi tersebut. Bahkan tidak sedikit kopontren yang gulung tikar karena terlalu banyak utang oleh santrinya sendiri. Pengelolaan utang juga merupakan permasalahan dalam koperasi

${ }^{5}$ Misjaya, Didin Saefuddin Bukhori, Adian Husaini, Ulil Amri Syafri, Konsep Pendidikan Kemandirian Ekonomi di Pondok Pesantren Mukmin Mandiri Sidoarjo-Jawa Timur, Edukasi Islami, Vol. 8, No. 1, 2019, h. 91-108.

6 Chusmeru, Masrukin, Sri Pangestuti, Koperasi Pondok Pesantren Sebagai Pemberdayaan Ekonomi Santri, Prosiding Seminar Nasional dan Call for Paper "Pengembangan Sunber Daya Perdesaan dan Kearifan Lokal Berkelanjutan VII, 17-18 November 2017, Purwokerto, h. 990-998. 
pesantren. Dilematis pada permintaan utang ini karena beberapa barang yang tidak memiliki daya tahan lama, dan harus terjual dalam waktu cepat. Selain itu, kopontren hanya memiliki pasar di kalangan santri dan sedikit pada wali santri, itu pun ketika wali santri sedang berkunjung ke pesantren saja.

K. H. Abdul Halim pada Pesantren Santi Asmoro membangun bengkel kerja, poliklinik, serta koperasi untuk memperbaiki serta meningkatkan taraf kehidupan melalui bidang ekonomi.7 Ini adalah salah satu bentuk perubahan yang terjadi pada pondok pesantren. Adanya keterampilan berbasis teknik ini meningkatkan sumberdaya santri ketika sedang menjadi santri dan pada saat sudah menjadi alumni pondok pesantren. Bengkel kerja merupakan pengembangan dari kegiatan ekstrakurikuler pesantren yang tidak tersistematis.

Seorang santri di pondok pesantren tidak hanya belajar mengenai ilmu-ilmu agama. Para santri juga mempelajari bekal keterampilan yang dibutuhkan untuk menjadi bagian dari masyarakat global. Hal ini yang menjadi salah satu landasan pesantren Santi Asmoro dalam mengembangkan sumberdaya santri dalam ranah teknik dan ekonomi. Kegiatan ekstra santri yang sebenarnya sering disebut dengan gotong royong seperti gotong royong dalam mendirikan bangunan baru atau merenovasi bangunan lama pondok pesantren. Peran yang diambil oleh santri pada kegiatan ini seperti menjadi arsitektur dadakan, kepala tukang, pelayan tukang, hingga menjadi seksi konsumsi bagi santri yang sedang bekerja. Selama masa pembangunan, biasanya beberapa kegiatan utama dikurangi dan kedisiplinan dilonggarkan, mengingat santri harus membagi waktunya untuk mengaji dan menjadi pekerja teknik.

Pesantren tidak hanya mendakwahkan tentang sholat maupun mengaji, tetapi juga tentang berprilaku ekonomi yang sesuai dengan kaidah Islam. ${ }^{8}$ Berprilaku ekonomi menjadikan santri dalam bersikap mampu melibatkan prinsip efektif dan efisien. Hal ini sebenarnya pengamalan dari mencegah hal yang sia-sia atau mubadzir. Prilaku yang efektif mengarahkan santri untuk bertindak sesuai dengan tujuan. Sedangkan perilaku yang efisien mengarahkan santri untuk mempertimbangkan kebergunaan sumber daya yang diperlukan untuk mencapai tujuan. Jadi tidak ada usaha dan sumber daya yang terbuah siasia atau terlalu berlebihan. Penjelasan di atas adalah prilaku ekonomi yang filosofis. Adapun prilaku ekonomi pada tatanan praktiknya adalah keterlibatan santri dalam kegiatan ekonomi. Maka ilmu agama dan prilaku ekonomi filosofis inilah yang menjadi dasarnya agar santri bisa berprilaku ekonomi yang berdasarkan syariat Islam.

7 Asep Saefullah, K. H. Abdul Halim dan Gagasan Pendidikan Ekonomi Berbasis Pesantren, Jurnal Lektur Keagamaan, Vol. 15, No. 1, 2017, h. 177-206.

8 Mohammad Nadzir, Membangun Pemberdayaan Ekonomi di Pesantren, Economica, Vol. 6, No. 1, 2015, h. 37-56. 
Produksi barang oleh santri seperti yang dilakukan oleh santri di Pesantren Darul Ulum Pamekasan meliputi air minum kemasan, es balokan, camilan, serta beberapa kerajinan handmade yang mana pemasaran ditujukan kepada santri sendiri dan masyarakat. ${ }^{9}$ Kegiatan inovasi santri yang berpeluang untuk menghadapi globalisasi khusunya pada ekonomi juga diwujudkan oleh para santri di pondok pesantren Darul Ulum Pamekasan. Kategori inovasi yang berbasis hasil karya dari santri sendiri adalah pengolahan terhadap bahan dasar dan pengolahan pada barang setengah jadi. Pengolahan air mineral menjadi air mineral kemasan yang bermerk atas nama pesantren sendiri, produksi es balokan, serta pembuatan camilan adalah proses pengolahan oleh santri yang ditujukan untuk santri sendiri dan masyarakat. Selain itu, para santri juga meningkatkan kreatifitasnya pada pembuatan kerajinan berbasis handmade untuk dijadikan souvenir khas dari pondok pesantren. Pesantren ini mempromosikan keberadaan santri sebagai bagian dari masyarakat yang mampu mengimbangi persaingan global dalam tingkat daerah. Terobosan minimalis ini setidaknya membuka kacamata masyarakat bahwa seorang santri memiliki selain memiliki pengetahuan agama yang dalam, juga memiliki keterampilan dalam bersaing di era global.

Inovasi selanjutnya dilakukan oleh para santri di daerah Cilacap. Pesantren Rubat Mbalong di Cilacap memiliki beberapa sector usaha seperti pertanian dan holtikultura, peternakan, perikanan, toko bahan bangunan, kopontren, handy craft, dan laundry. ${ }^{10}$ Selangkah lebih maju, pesantren ini memudahkan mengintegrasikan pola perusahaan ke dalam dunia pesantren. adanya pembagian sector usaha menjadi beberapa bagian seperti sector pertanian dan holtikultura, peternakan, perikanan, toko bahan bangunan, kopontren, handycraft dan laundry. Dari beberapa sector ini dapat disimpulkan bahwa pesantren lebih berfokus pada produksi atau distribusi bahan baku. Argumentasi pesantren dalam pemusatan usaha pada produksi bahan baku ini adalah kemudahan dalam memasarkan dan memberikan peluang bagi santri untuk berkreasi terhadap hasil produksi bahan baku dari pesantren.

Sebenarnya kegiatan ekonomi pesantren tidak luput dari perhatian pemerintah, ${ }^{11}$ dengan kata lain pemerintak tetap memberikan harapan dan perhatian dengan keberadaan pesantren sebagai penopang ekonomi Negara. Pemerintah memiliki peran yang signifikan dalam peningkatan lembaga pendidikan ilmu agama seperti pesantren di Indonesia. Tidak

${ }^{9}$ Rudy Haryanto, Menumbuhkan Semangat Wirausaha Menuju Kemandirian Ekonomi Umat Berbasis Pesantren (Studi Kasus di PP Darul Ulum Banyuanyar Pamekasan), Nuansa, Vol. 14, No. 1, 2017, h. 185-212.

10 Fitria Nurul Azizah, Musyafa Ali, Pembangunan Masyarakat Berbasis Pengembangan Ekonomi Pesantren, Jurnal Ilmiah Ekonomi Islam, Vol. 6, No. 3, 2020, h. 645653.

11 Ujang Suyatman, Pesantren dan Kemandirian Ekonomi Kaum Santri (Kasus Pondok Pesantren Fathiyyah Al-Idrisaiyah Tasikmalaya), Al-Tsaqafa, Vol. 14, No. 2, 2017, h. 303-315. 
hanya mendukung dari segi perizinan maupun pendanaan. Tetapi juga mendukung dari segi promosi terhadap aktivitas santri yang berpotensi untuk meningkatkan sumberdaya manusia yang berada di lingkungan pesantren maupun di luar pesantren. secara tidak langsung sebuah pesantren memiliki konstruksi sosial yang sama dengan satu kelurahan. Sistem sosial yang dibangun oleh pesantren berpusat pada satu kepemimpinan yaitu pada pengasuh pesantren. kepemimpinan terpusat ini dibantu oleh beberapa asisten yaitu dewan asatidz atau disebut juga terkadang sebagai santri senior yang mengabdikan diri pada pesantren, dan yang terakhir adalah para santri itu sendiri. Maka tidak mengherankan jika santri memiliki kemampuan adaptasi tinggi ketika berada dalam lingkungan yang heterogen. Adapun inovasi pesantren dalam membekali para santrinya untuk memiliki keterampilan tambahan yang berguna untuk masyarakat merupakan sebuah pemikiran inovatif dari pimpinan pesantren yang memperhatikan perkembangan zaman.

Dukungan pemerintah dalam memaksimalkan promosi kegiatan pesantren yang berbasis usaha keterampilan dapat meningkatkan eksistensi pesantren di dunia kerja. Sekarang ini stigma masyarakat yang belum mengenal pesantren dan lulusan pesantren cenderung memendang sebelah mata, karena terlalu terpaku pada kesimpulan bahwa seirang santri itu hanya memiliki kemampuan pada bidang keagamaan saja. Padahal melalui terobosan dari beberapa pesantren dalam membangun kebudayaan santripreneurship telah membuktikan bahwa pesantren memiliki andil besar dalam perkembangan sumberdaya manusia di dalam suatu wilayah.

Pesantren tidak hanya berfungsi sebagai lembaga pendidikan ekonomi syariah, tetapi juga sebagai laboraturium pengkajian ekonomi syariah; forum ekonomi syariah; Islamic economy centre; serta menjadi inspirasi dalam konteks pengembangan ekonomi syariah. ${ }^{12}$ Ini merupakan peran pesantren yang memokuskan pada penanaman standar kajian syariah pada bidang ekonomi. Ada dua jenis kegiatan pengkajian ekonomi berbasis syariah pada pesantren yaitu pendidikan ekonomi syariah dan laboraturium pengkajian ekonomi syariah. Pada ranah pendidikan, pesantren berusaha menanamkan pengetahuan terhadap santri atau khalayak umum tentang teori dan tata cara melakukan kegiatan perekonomian yang berdasarkan syariat Islam. Kegiatan ini mendukung adanya kemudahan bagi masyarakat yang notabene masih awam terhadap kegiatan ekonomi yang dikonsepsi secara islami. Kebanyakan masyarakat hanya mengetahui tentang jual beli yang tidak melibatkan barang haram, timbangan yang tidak sesuai dengan standar, dan mentransaksikan barang yang tidak layak jual. Sedangkan untuk ketentuan lainnya seperti bagi hasil, kerja sama atau afiliasi beberapa

${ }^{12}$ Muhammad Zuhirsyan. Membidik Potensi Ekonomi Syariah di Lembaga Pendidikan Pondok Pesantren, Economica, Vol. 9, No. 2, 2018, h. 319-347. 
individu yang memiliki modal belum diketahui oleh masyarakat maupun santri secara penuh. Sehingga pesantren terlebih dahulu memberikan pengetahuan yang merupakan dasar dari tindakan ekonomi islami yang akan dipraktikkan oleh santri dan masyarakat.

Selanjutnya adalah pendirian laboratorium pengkajian ekonomi syariah. Salah satu objek dari laboratorium ini adalah penyediaan tenaga ahli yang berkompeten dalam menganalisis sebuah kegiatan yang berkaitan dengan ekonomi syariah. Laboratorium mengaplikasikan kaidah-kaidah islam dalam menganalisis permasalahan ekonomi yang beredar dan berlaku di masyarakat. Tujuannya adalah untuk menemukan solusi jika terdapat permasalahan atau perdebatan, serta memberikan pengalaman kepada santri untuk mengetahui kehidupan ekonomi di dunia nyata. Disamping laboratorium ini, pesantren juga mengadakan forum ekonomi syariah yang diadakan dalam jangka waktu tertentu. Fungsi dari forum ini adalah untuk mengumpulkan, menjaring, dan menginformasikan tentang temuan dan perkembangan ekonomi kepada khalayak umum. Melalui forum ini akan dibahas mengenai permasalahan dan rencana-rencana inovatif yang dilakukan pesantren pada bidang ekonomi. Tujuan umumnya adalah menjadikan pesantren sebagai pusat kajian ekonomi yang berbasis syariah dan memberikan inspirasi bagi pesantren lain maupun pelaku ekonomi secara umum.

Pesantren juga bisa memberikan pelatihan resmi seperti pelatihan kewirausahaan, pelatihan koperasi pesantren, lokakarya koperasi syariah, dan pemberian motivasi kewirausahaan terhadap santri. ${ }^{13}$ Pesantren yang berperan sebagai sarang ilmu pengetahuan agama sudah semestinya menjadi rujukan dalam mengadakan pelatihan atau keterampilan yang melibatkan pengetahuan agama. Jadi kegiatan pelatihan dan keterampilan tidak hanya diselenggarakan oleh lembaga formal, melainkan pesantren juga harus dilibatkan sebagai ahli agama yang khusus memberikan muatan-muatan agama yang berkaitan dengan pelatihan tersebut. tidak terkecuali pelatihan dalam bidang ekonomi seperti pelatihan kewirausahaan, pelatihan pendirian dan pengelolaan koperasi pesantren, lokakarya pada koperasi syariah, dan penanaman motivasi kewirausahaan bagi santri. Pelatihan kewirausahaan bagi santri memberikan dampak positif, karena pelatihan ini membekali santri untuk menghadappi dunia nyata setelah mereka selesai belajar ilmu agama di pesantren. Berwirausaha adalah pekerjaan yang bisa dilakukan oleh siapa saja tanpa memerlukan ijazah atau sertifikat khusus. Biasanya wirausaha membutuhkan jaringan komunikasi dan permodalan.

Pada dua hal yang membangun kewirausahaan ini, keunggulan pesantren dapat dimunculkan. Keunggulannya yaitu asas kekeluargaan yang dibangun oleh pesantren terhadap seluruh santrinya baik santri

13 Aning Kesuma Putri, Eka Fitriyanti, Ayu Wulandari, Empowerment Ekonomi Pesantren, E-DIMAS, Vol. 12, No. 1, 2021, h. 191-196. 
maupun alumni. Sehingga dengan menyebutkan kesamaan almamater, maka kemudahan dalam membentuk jaringan komunikasi ekonomi lebih mudah dan tentunya memiilki perlakuan yang berbeda dengan orang lain. Adapun pada segi permodalan, santri diberikan pengetahuan tentang konsep perkreditan yang islami, sehingga tidak ditemukan pada prakteknya unsur riba.

Pelatihan terhadap pendirian dan pengelolaan koperasi pesantren biasanya diselenggarakan oleh pesantren yang ditunjuk sebagai model unggulan dalam mengelola koperasi pesantren. Sama halnya dengan lembaga-lembaga keuangan lainnya yang memiliki jaringan hubungan dalam rangka meningkatkan kinerja. Maka pada pelatihan koperasi pesantren ini dapat mendongkrak pendapatkan pesantren. Perlu disadari bahwa, sebuah pesantren dalam konsep ekonomi, adalah sebuah pangsa pasar yang pasti bagi koperasi pesantren. Karena para santri tidak mungkin untuk bertransaksi diluar pesantren apabila koperasi pesantren telah menyediakan semua barang kebutuhan. Hal ini bukan kapitalisasi pesantren, melainkan salah satu bentuk usaha pesantren dalam mengalirkan pengeluaran pesantren maupun pengeluaran santri agar bisa tetap digunakan untuk kemajuan dan pembangunan pesantren.

Kemudian motivasi adalah unsur pendukung dari dalam diri santri ayng perlu dibangun untuk meningkatkan kemauan santri dalam berwirausaha. Menyadarkan santri untuk berwirausaha juga memiliki kendala dan tantangan besar. Tidak semua santri menyadari bahwa usaha bisa dibangun melalui silaturrahim dan saling percaya. Karakter amanah yang diajarkan oleh Rasulullah sangat relevan dengan kegiatan ekonomi yang tanpa permodalan. Pemberian kepercayaan antara pemberi modal dan pengusaha harus dijaga dengan baik. Sebaiknya juga diadakan surat kesepakatan antara dua belah pihak untuk mencegah adanya permasalahan dikemudian hari. Pemberian informasi mengenai cara mendapatkan barang yang murah, serta penyedia barang dengan berbagai kualitasi terhadap santri dapat memacu motivasi santri. Karena pengetahuan santri tentang dunia kewirausahaan terbuka.

Keberadaan pesantren memberi berkah terhadap masyarakat sekitar pesantren. Pemberdayaan masyarakat dalam kegiatan pemenuhan kebutuhan harian maupun musiman pesantren menjadi ajang kolaborasi kegiatan ekonomi antara pesantren dengan masyarakat. ${ }^{14}$ Peran pesantren menjadi pembangkit perekonomian daerah adalah dengan melakukan kerja sama antara pesantren dengan masyarakat. Kerjasama ini bersifat mutualisme. Penyediaan barang baku yang saling membutuhkan antara pesantren dan masyarakat menjadikan perputaran keuangan yang saling menguntungkan.

${ }^{14}$ Syahrul Falah, Irham Zaki, Pemberdayaan Ekonomi Masyarakat ala Pondok Pesantren di Kelurahan Kejawan Putih Tambak Surabaya, Jurnal Ekonomi Syariah Teori dan Terapan, Vol. 4, No. 4, 2017, h. 340-345. 
Tidak hanya penyediaan barang, tetapi juga penyediaan kebutuhan. Misalnya pesantren melalui santri-santrinya memberikan pengetahuan keagamaan pada masyarakat melalui pengajian rutinan yang diadakan oleh masyarakat dan diisi oleh para santri. Selain itu, santri juga terjun kemasyarakat dalam kegiatan pembimbingan dan pengawasan kegiatan beragama masyarakat. Sedangkan masyarakat memberikan timbal balik yaitu turut serta dalam pelayanan pesantren, seperti menjadi jasa laundry santri, tukang masak, serta pemeliharaan sarana prasarana pesantren. keterlibatan santri dan msyarakat dalam pesantren dan lingkungan sekitar pesantren menimbulkan hubungan saling menguntungkan. Sehingga melalui hubungan ini diharapkan terciptanya kehidupan yang harmonis antara dua kelompok individu yang besar.

Peran pesantren selain akan bertambah sebagai peningkatan ekonomi masyarakat dalam mendukung program pemerintahan. 15 Program pemerintah yang memiliki tujuan umum untuk mensejahterakan rakyatnya telah dibantu dengan keberadaan pesantren di wilayah tersebut. secara tidak langsung. Pesantren merupakan lapangan pekerjaan atau peluang wirausaha baru bagi masyarakat sekitarnya. Kehidupan santri di pesantren, serba memiliki keterbatasan seperti waktu dan pendanaan. Santri tidak memiliki banyak waktu untuk bersinggungan dengan dunia luar. Selain itu santri juga memiliki keterbatasan pendanaan. Tidak semua santri memiliki manajemen keuangan diri yang bagus. Santri pada umumnya memiliki pengalaman dalam hutang. Maka biasanya santri dapat memiliki tempat langganan untuk menyandarkan pendanaannya selama beberapa hari. Pesantren biasanya menyediakan koperasi pesantren untuk menganggulangi permasalahan ini, dan solusi kedua adalah pada kios atau warung yang didirikan oleh warga sekitar pesantren. sebenarnya melalui kegiatan utang piutang ini membuat hubungan emosional yang erat antara santri dan masyarakat, termasuk juga di dalamnya terjadi perputaran uang yang bisa dipantau dengan baik. Karena santri sebagai pihak yang berhutang diketahui dengan jelas keberadaannya oleh pihak yang dihutangi.

Sebenarnya para santri antusias dalam menerima pendidikan ekonomi. ${ }^{16} \mathrm{Hal}$ ini semakin menunjukkan bahwa lulusan pesantren adalah individu yang siap menatap ekonomi global. Antusisme ini tidak luput dari penanaman motivasi dan karakter untuk berlaku mandiri ketika santri telah lulus dari pesantren. Seseorang yang memiliki pengetahuan agama memiliki nilai lebih dalam melakukan kegaitan apapun, contohnya adalah dalam kegiatan ekonomi. Santri dalam berprilaku ekonomi sudah masti menerapkan dasar-dasar agama Islam

\footnotetext{
15 Nenden Maesaroh, Yani Achdiani, Tugas dan Fungsi Pesantren di Era Modern, Sosietas, Vol. 7, No. 1, 2017, h. 346-352.

16 Ayuniva Recinta Nuraeny Putri, Wahjoedi, Agung Haryono, Pembelajaran Ekonomi di Pondok Pesantren, Jurnal Pendidikan, Vol. 3, No. 4, 2018, h. 424-429.
} 
dan memperhatikan kaidah-kaidah hukum Islam yang berlaku pada bidang ekonomi. Santri juga melalui pengalamannya ketika di pesantren, akan lebih memperhatikan kemaslahatan bersama. Karena melalui pendidikan moral di pesantren, diajarkan untung saling memberi manfaat dan tidak saling merugikan satu sama lainnya.

Dalam pemberdayaan ekonomi sosial harus memperhatikan kearifan lokal dan karakter budaya khas Indonesia serta tetap berpegang teguh pada ajaran Islam. ${ }^{17}$ Salah satunya adalah pesantren yang merupakan lembaga pendidikan Islam khas Indonesia dimana pembelajar berdiam di rumah pengajar dalam kurun waktu yang lama. Kegiatan utama dalam pesantren ini adlaah mengkaji ilmu agama. Maka segala ranah kehidupan harus didasari pada pengetahuan agamanya, tidak terkecuali pada ranah ekonomi. Praktik ekonomi bukan dari transaksi upah mengajar pengajar pada pesantren, melainkan pada pemenuhan kebutuhan sehari-hari. Dalam pemenuhan kebutuhan harian ini penyelenggaranya adalah santri, dan pembelinya juga santri. Termasuk juga pada praktiknya melibatkan masyarakat untuk memberikan pengalaman bagi santri dalam melakukan praktik ekonomi secara nyata.

Program pendidikan dan penerapan investasi juga diperlukan untuk menjadi materi terhadap santri untuk memberikan ruang luas santri dalam berperilaku ekonomi. ${ }^{18}$ Inovasi lebih lanjut adalah pemberian pengetahuan mengenai dunia investasi. Pelibatan materi investasi bagi santri adalah membuka peluang kekerabatan bagi para santri dalam melakukan kegiatan kewirausahaan. Setidaknya melalui investasi ini, ada pemodal dan ada yang mengelola permodalan. Pengenalan investasi ini menjembatani bagi santri dengan tingkat ekonomi tinggi dan rendah. Melalui kegiatan investasi, diharapkan nantinya akan terwujud hubungan kekerabatan yang erat dengan satu kegiatan yang memiliki visi yang sama antara dua pemodal dan pengelola modal.

Pesantren harus memiliki permodalan yang kuat untuk bisa menggerakkan ekonomi masyarakat sekitar. ${ }^{19}$ Permodalan diperoleh dari pengelolaan keuangan yang baik oleh pesantren. dana awal ketika pesantren dalam memenuhi usaha awalnya tidak harus selalu melimpah atau mencukupi. Terutama yang menjadi dasar adalah permodalan yang disediakan oleh pesantren mampu menggerakkan ekonomi di lingkungan pesantren sendiri. Pergerakan ekonomi pada pesantren kemudian

${ }_{17}$ Muhammad Nafik Hadi Ryandono, Peran Pondok Pesantren dalam Pemberdayaan Sosial Ekonomi di Jawa Timur pada Abad ke-20, Mozaik Humaniora, Vol. 18, No. 2, 2018, h. 189-204.

${ }^{18}$ Adhi Iman Sulaiman, M. Masrukin, C. Chusmeru, Sri Pangestuti, Pemberdayaan Koperasi pondok Pesantren sebagai Pendidikan Sosial dan Ekonomi Santri, Jurnal Pendidikan dan Pemberdayaan Masyarakat, Vol. 3, No. 2, 2016, h. 109-121.

19 Muhammad Anwar Fathoni, Ade Nur Rohim, Peran Pesantren dalam Pemberdayaan Ekonomi Umat di Indonesia, Conference on Islamic Management, Accounting, and Economics (CIMAE) Proceeding, Vol. 2, 2019, h. 133-140. 
dievaluasi secara berkala untuk mengetahui peningkatan dan penurun kinerja usaha. Adapun ekspansi ekonomi pesantren ke masyarakat yang berperan sebagai pendukung atau penggerak ekonomi masyarakat sekitar memerlukan kemapanan yang tinggi dari pesantren tersebut.

\section{Simpulan}

Pesantren tidak bisa dipandang sebelah mata dan dikesampingkan ketika berbicara tentang kemajuan. Dengan kemandirian dan kemapanannya dalam mengelola sebuah lembaga, maka keadaan ini menjadikan pesantren mampu membuat terobosan dan inovasi untuk meningkatkan perannya di dalam masyarakat. Dalam menghadapi globalisasi, perekonomian sekarang sangatlah mendukung peradaban. Terlebih lagi setelah masa pandemi, yang mengharuskan masyarakat untuk memulihkan kembali perekonomian. Pesantren sudah mulai mempersiapkan santrinya menjadi agen perubahan dan peningkatan kehidupan masyarakat yang berbasis pada hukum-hukum Islam. Di samping pembekalan pada ajaran agama Islam, juga diberikan pembekalan pada kemampuan berwirausaha dan bersosialisai. Sehingga pada saat santri sudah terjun ke masyarakat, ia mampu mengintegrasikan pengetahuan agama dan pengetahuan sosialnnya dengan baik

\section{Referensi}

Adhi Iman Sulaiman, M. Masrukin, C. Chusmeru, Sri Pangestuti, Pemberdayaan Koperasi pondok Pesantren sebagai Pendidikan Sosial dan Ekonomi Santri, Jurnal Pendidikan dan Pemberdayaan Masyarakat, Vol. 3, No. 2, 2016.

Ahmad Fauzi, Pengembangan Ekonomi Islam di Pesantren Jawa Timur, AlUlum, Vol. 17, No. 1, 2017.

Aning Kesuma Putri, Eka Fitriyanti, Ayu Wulandari, Empowerment Ekonomi Pesantren, E-DIMAS, Vol. 12, No. 1, 2021.

Asep Saefullah, K. H. Abdul Halim dan Gagasan Pendidikan Ekonomi Berbasis Pesantren, Jurnal Lektur Keagamaan, Vol. 15, No. 1, 2017.

Ayuniva Recinta Nuraeny Putri, Wahjoedi, Agung Haryono, Pembelajaran Ekonomi di Pondok Pesantren, Jurnal Pendidikan, Vol. 3, No. 4, 2018.

Chusmeru, Masrukin, Sri Pangestuti, Koperasi Pondok Pesantren Sebagai Pemberdayaan Ekonomi Santri, Prosiding Seminar Nasional dan Call for Paper "Pengembangan Sunber Daya Perdesaan dan Kearifan Lokal Berkelanjutan VII, 17-18 November 2017, Purwokerto, hal. 990-998.

Fitria Nurul Azizah, Musyafa Ali, Pembangunan Masyarakat Berbasis Pengembangan Ekonomi Pesantren, Jurnal Ilmiah Ekonomi Islam, Vol. 6, No. 3, 2020.

Misjaya, Didin Saefuddin Bukhori, Adian Husaini, Ulil Amri Syafri, Konsep Pendidikan Kemandirian Ekonomi di Pondok Pesantren Mukmin Mandiri Sidoarjo-Jawa Timur, Edukasi Islami, Vol. 8, No. 1, 2019. 
Mohammad Nadzir, Membangun Pemberdayaan Ekonomi di Pesantren, Economica, Vol. 6, No. 1, 2015.

Muhammad Anwar Fathoni, Ade Nur Rohim, Peran Pesantren dalam Pemberdayaan Ekonomi Umat di Indonesia, Conference on Islamic Management, Accounting, and Economics (CIMAE) Proceeding, Vol. 2, 2019.

Muhammad Nafik Hadi Ryandono, Peran Pondok Pesantren dalam Pemberdayaan Sosial Ekonomi di Jawa Timur pada Abad ke-20, Mozaik Humaniora, Vol. 18, No. 2, 2018.

Muhammad Zuhirsyan. Membidik Potensi Ekonomi Syariah di Lembaga Pendidikan Pondok Pesantren, Economica, Vol. 9, No. 2, 2018.

Nenden Maesaroh, Yani Achdiani, Tugas dan Fungsi Pesantren di Era Modern, Sosietas, Vol. 7, No. 1, 2017.

Rudy Haryanto, Menumbuhkan Semangat Wirausaha Menuju Kemandirian Ekonomi Umat Berbasis Pesantren (Studi Kasus di PP Darul Ulum Banyuanyar Pamekasan), Nuansa, Vol. 14, No. 1, 2017.

Siti Nurhayati, Nurjamil, Model Pemberdayaan Ekonomi Masyarakat Miskin melalui Akses pembiayaan Bank Wakaf Mikro Berbasis Pesantren (Studi Kasus LKM Syariah Ranah Indah Darussalam Ciamis), Eco-Iqtishodi, Vol. 1, No. 1, 2019.

Syahrul Falah, Irham Zaki, Pemberdayaan Ekonomi Masyarakat ala Pondok Pesantren di Kelurahan Kejawan Putih Tambak Surabaya, Jurnal Ekonomi Syariah Teori dan Terapan, Vol. 4, No. 4, 2017.

Toha Maksum, Muh. Barid Nizarudin Wajdi, Pengembangan Kemandirian Pesantren Melalui Program Santripreneur, Jurnal Pengabdian Kepada Masyarakat, Vol. 2, No. 2, 2018.

Ugin lugina, Pengembangan Ekonomi Pondok Pesantren di Jawa Barat, Risalah, Vol. 4, No. 1, 2018.

Ujang Suyatman, Pesantren dan Kemandirian Ekonomi Kaum Santri (Kasus Pondok Pesantren Fathiyyah Al-Idrisaiyah Tasikmalaya), Al-Tsaqafa, Vol. 14, No. 2, 2017. 